\title{
Developmental Differences: The Role of Institutions in Oil and Gas Operations within the State of Colorado
}

\author{
By: John Taylor Stafford ${ }^{1}$
}

I argue differences in institutional design choices governing western lands have demonstrable effects in the extraction of shale resources. Using GIS data on geographic characteristics and shale development data, I create a dataset which allows a spatial link between institutions, natural resource development, and other parcel metrics. This allows for a test of how institutions governing property affect shale development. Employing a border discontinuity, I indicate that Native American land experiences extensively more shale development, compared to the neighboring private, state, and federal lands containing similar potential for shale development. In sum, this study contributes to the property rights scholarship by providing empirical evidence on how institutional design choices governing property rights affect the development of a natural resource. My analysis further suggests how institutional choices over the governance of natural resources can increase the cost of extracting the resource within one institutional choice, while also transferring development to the less costly institutional choice.

\footnotetext{
${ }^{1}$ The author would like to thank Taylor Jaworski and Eric Alston for generous comments and insights. The author would also like to thank the Hernando de Soto Capital Markets Program for research support. The author would also like to thank the Economics department at the University of Colorado Boulder.
} 


\section{Introduction}

The extraction of natural resources in the frontier U.S. West drove both the settlement and historical development of the region. The public policy of economic development coupled with a high degree of local de facto control drove the definition of rights to natural resources. Despite the identical underlying interest of natural resource extraction, the emergence of rights regimes in different jurisdictions did not produce similar property rights. The property rights defined on Native American lands differed significantly compared to those that resulted from the settlement of other western lands. Where western lands, in general, advanced by establishing institutional rule sets that created an environment for development, Native American de jure rights were defined from solely institutional choices that hindered development. Given that the historical and current purpose of rights formation is to promote the economic development of the region, ${ }^{2}$ how have these institutional arrangements affected current natural resource development? I argue that the variation in institutional choices from those on private land to those on Native American lands, have demonstrable effects. More specifically, I contend that the variation in institutional development between rights formation on federal, state, and private land compared to Native American land directly impact shale development.

This study is motivated by the previous scholarship on the role of institutions in producing economic development. However, empirically identifying the role of institutions in generating economic outcomes tends to be difficult due to the endogeneity of institutions. I overcome this problem and contribute to this scholarship by using a natural experiment of resource development. By using GIS data on shale development within the State of Colorado, I am able to link institutional variation to shale development. This data, in combination with a technique similar to regression discontinuity, overcomes the endogeneity problem associated with institutions and economic development. Therefore, I contribute to the existing literature by empirically measuring the role institutional choices affect the development of a natural resource.

\footnotetext{
${ }^{2}$ Patricia, Limerick. The Legacy of Conquest: The Unbroken Past of the American West (Norton, 2006). See COGCC v. Martinez, No. 12SC297 22-23 (CO. 2019). "The Commission is required to foster the development of oil and gas resources, protecting and enforcing the rights of owners and producers, and in doing so, to prevent and mitigate significant adverse environmental impacts to the extent necessary to protect public health, safety, and welfare, but only after taking into consideration cost-effectiveness and technical feasibility." (emphasis added). This recent decision by the Colorado Supreme Court underpins the western view of using natural resources and protection of private property to promote economic development takes a primary role over other considerations, including environmental considerations.
} 
The study is further motivated by the economic literature on the resource curse. I contribute to the literature on the natural resource curse by providing evidence that natural resource booms incentivize institutional design choices that promote further development of the resource.

Section I summarizes the formalization of property rights in the West to demonstrate the role these rights regimes led to disparities in current land governance institutions. Section II provides the legal history surrounding the regulation of shale among federal, state, and Native American lands. Section III explains the uses of border discontinuity to model the effect of institutions on shale development. Section IV provides an empirical test of this question, followed by my discussion of the results.

\section{Land Development in the West}

The economic analysis on the development of natural resources has primarily centered upon choices by policymakers and participants in defining the rights to the extraction of a natural resource. In this section, I present the relevant literature and situate my intended contribution therein.

\section{A. Formalization of Property Rights}

The western United States is a context to understand the extent to which choices by policymakers and participants play in the definition of property rights surrounding natural resources. The resource scarcity of the West, from water to the more modern resources of shale, aids in the definition of rights surrounding the resource. As Harold Demsetz identified, scarcity is a primary driver in defining property rights (Demsetz, 1967). Localized control over these resources, by participants and local governments, can also define the rights to the resource (Anderson \& Hill, 2004). This is because, provided participants cooperate in the enforcement of rights to the resource, the collective enforcement aids in the definition of the rights to the resource (Alston, Harris, \& Mueller, 2012). Ellickson (1991) demonstrated such a collective enforcement mechanism among California cattle ranchers in defining property right boundaries. The mechanisms of defining property rights, through the resource itself, localized control, and collective enforcement, did not always correspond to the more formal institutional arrangements surrounding the resource.

An example of the conflict over a formal rights system and the allocation of a scarce resource is water. Water is a critical resource in the West due to its economic uses and relative 
scarcity. The uses and relative scarcity of water caused the definition of rights to water to develop much more quickly than other rights systems (Leonard \& Libecap, 2016). The development of water rights, therefore, displays the extent to which the scarcity of a resource, participants themselves, and the legal system play in the definition of a formal rights system (Alston \& Stafford, 2018). This is one example of the historical development of resources in the western United States and displays how institutions can influence the development of property rights, for better and for worse.

The development of shale rights has followed similar patterns to that of water, and other property rights within the West. The economic uses of shale, from industrial uses in heating and power systems to the electric power sector for generating electricity, ${ }^{3}$ and the scarcity of shale are such that institutional rule sets will be chosen that maximize the extraction of shale. Therefore, understanding how these institutional arrangements affect the development of the resource is a central motivation of my analysis here. The use of localized control, the scarcity of the resource, and collective enforcement all have aided in the definition of the rights surrounding the resource. However, just like water rights development, shale development has seen variance in institutions. Thus, I clarify the ways in which variance in shale institutions affects the development of the underlying resource.

\section{B. The Native American Experience}

The formalization of property rights regimes in the West did not map similarly to the Native American experience. Unlike most western lands where the land was generally governed by institutional choices with lower transaction costs, the development of Native American lands experienced institutional structures with high transaction costs. By the late 1800s, federal Native American policy had exercised a series of land grabs and governance over Native American lands (Royster, 1994). These land grabs included: designating specific boundaries to Native American 'reservations' (General Allotment Act, 1887); the United States obtaining sole title to the land designated to the tribe (Cherokee Nation v. Georgia, 30 U.S. (5 Pet.) 1 (1831)), and timber solely belonging to the federal government (United States v. Cook, 86 U.S. 591 (1873)). The land grabs generated heterogeneous land units that were not in direct control by the Native Americans. Instead, the federal government was the trustee over these lands. This trusteeship

\footnotetext{
${ }^{3}$ See https://www.eia.gov/energyexplained/index.php?page=natural_gas_use
} 
ended in 1934 with the Indian Reorganization Act (25 U.S.C. Ch. 14). However, decisions regarding land use were subject to constraints by the federal government (Anderson \& Leuck, 1992). The federal control over Native American land makes development extremely difficult, especially for mineral development; since Native Americans are the sole "beneficial owner[s] of that natural resources" (United States v. Shoshone Tribe of Indians, 304 U.S. 111 (1938); Regan, 2018).

The Native American experience differs significantly from the development of the rest of the West. While other parts of the West were generally developed using active participation by settlers and institutions, the Native American experience has not resulted in the same property rights regimes. Generally, this experience has led to severe under-development within Native American Reservations. This is due to the fact that the historical policies identified did not allow Native Americans to govern their own economic development. However, the change in the federal public policy of Native American governance, beginning in 1934, allowed the Southern Ute Native American Reservation to obtain more control over the ownership of their lands. ${ }^{4}$ This change in ownership of property, from federal control to Southern Ute control, allowed the Ute to structure their own institutions to aid in the development of their natural resource endowments and ultimately foster economic development. ${ }^{5}$ The Southern Ute development pattern is an example of how well-defined property rights can spur development, a mechanism consistent with the views of economic development scholars (North, 1990; De Soto, 2000, Acemoglu et. al., 2001, 2005). It is these institutional changes that I exploit in this paper to indicate how they can create differences in development.

\section{Legal History}

\section{A. Institutional Differences}

Federal, state, and Native American governance regimes show differences among each level. This gives each jurisdictional level the right to exercise power over how and where to

\footnotetext{
${ }^{4}$ Infra Section II, institutional differences regarding Native American Lands.

5 The elected member of the Southern Ute Indian Tribal Council speaking on the tribe's intent to establish their own institutional rules. "The Tribe's leaders believed that the Tribe could do a better job of monitoring its own resources than would the federal agencies...As [the tribe] have stated repeatedly to anyone who will listen to [them] 'We are the best protectors of our own resources and the best stewards of our own destiny; provided that we have the tools to use what is ours." Tribal Energy Resources: Reducing Barriers to Opportunity: Before The Committee on Oversight and Government Reform Subcommittee on the Interior, Energy, and Environment (2018) (Statement of Honorable Adam Red Councilman, Southern Ute Indian Tribal Council).
} 
regulate operations of the oil and gas industry and the incentive to expand this authority on the margins (Knight \& Gullman, 2015). As a result, it is critical to understand these differences and how the resultant variation in institutional design choices promote disparities in shale development.

The federal government tries to expand its power in the regulation of shale exploration. There is jurisdictional competition between the federal agencies over the management of oil and gas operations. ${ }^{6}$ This competition over the regulation of these operations results in uncertainty for participants within the industry, who do not know which agency, agencies or if any agency at all regulates an aspect of oil and gas development. ${ }^{7}$ The competition leads to the existing statutory definition to be rather incomplete, which results in a need for more local definition in order to provide clarity to the governance of oil and gas development.

States' institutional choices over the regulation of shale can cause disparities in its development. A prime example of this variation is New York and Pennsylvania and their respective views on the permitting of shale exploration within the Marcellus and Utica shale basin. In the case of New York, they have strictly forbidden shale development in the state; meanwhile, Pennsylvania has allowed development of the same shale basin (Robertson, 2016). These two opposing states provide institutional clarity in a policy debate where the federal regulations have been inconsistent. Despite the clarity, this example shows the importance of institutional arrangements on development. An institutional choice that restricts the development

\footnotetext{
${ }^{6}$ The BLM attempted to expand its authority by regulating "new well construction and testing requirements, new flowback storage requirements (tanks, not pits), new chemical disclosure requirements, and also generally increase the BLM's oversight" in hydraulic fracking on lands owned or held in the trust by the United States. Wyoming v. Zinke No. 16-8068 (10 ${ }^{\text {th }}$ Cir. 2017). However, this attempt by the BLM was held to be beyond the statutory authority of the BLM. Wyoming v. Zinke (10 ${ }^{\text {th }}$ Cir. 2017). While this policy dispute ended in 2017, it is worth noting this case because some of the wells within the dataset were approved in the years preceding 2017 and this attempt by the BLM may have influenced a firm's decision to obtain a well site on locations other than BLM land. The federal government has also attempted to regulate shale development by placing restrictions on environmental and the use of toxic materials. The most notable of these attempts are environmental legislation including: The Clean Air and Water Acts, National Environmental Policy Act of 1970 (NEPA), Resource Conservation and Recovery Act (RCRA), and Toxic Substance Control Act (TSCA). Grace Heusner, Allison Sloto and Joshua Ulan Galperin, "Defining and Closing the Hydraulic Fracturing Governance Gap," Denver Law Review 95 (2017): 191260.

${ }^{7}$ For example, under NEPA the Bureau of Land Management will "assess what environmental protection requirements a firm must meet in order to drill or produce oil and gas on a federal lease." Eric Lewis, "Patchwork Policies, Spillovers, and The Search for Oil and Gas," American Economic Journal: Economic Policy 11(1) (2019): 380-405.

On the other hand, the EPA will ensure safe management of wastewater, stormwater, and other waste. This overlapping of the EPA and the BLM in their management of environmental aspects of shale development is one of many contradictory rules that create uncertainty in the federal rules governing shale.
} 
of a resource does not reduce the overall production of the resource. Rather, the restriction of development by the institution displaces the development to a region where the governing institutional structure is more likely to encourage the extraction and development of the resource, for better or for worse. These choices and their impact on shale development are an area I explore in this paper.

Furthermore, within a state, local governments try to apply their comparatively limited authority to regulate and even ban shale exploration ${ }^{8}$ (Knight \& Gullman, 2015). The allowance of home-rule and other provisions, such that they do not conflict with the larger state law, generates differences even in local governance determining their own set of rules to the development of shale. The differences in these governance regimes, therefore, play a critical part in determining shale development within a region.

These institutional differences are also present on Native American Reservations. As previously discussed, the majority of Native American government's institutional choices of resource development are entrusted by the federal government. However, in the southwestern corner of Colorado is the Southern Ute Reservation. This reservation stands in stark contrast to other Native American governments' control over their natural resource development. In 1974, the tribal government placed a moratorium on issuing energy leases because the tribal government realized that the Department of the Interior was failing to properly negotiate compensation for losses to the reservation (Regan, 2018). During this moratorium, the tribal government mapped its underlying resources and created an institutional structure to allow more tribal control over the process of shale development by creating an in-house Energy Department (Tribal Energy Resources: Reducing Barriers to Opportunity, 2018). After the passage of the Indian Mineral Development Act (IMDA) (96 STAT. 1938), the tribe renegotiated shale development and generated even more tribal control over their resources. As a result of departing

\footnotetext{
${ }^{8}$ A clear example of local governments' attempts to use home-rule is in the case of the City of Longmont in the State of Colorado, which attempted to place a moratorium on shale exploration because of concerns over the environmental impacts of the exploration. COGA v. City of Longmont, No. 13CV63 (Colo. Dist. Ct. July 24, 2014). In this dispute, it was clear that attempts to apply home rule are applicable so long as they do not conflict with the larger state statutory law. This is due to the fact that Colorado, in its regulation of oil and gas operations, operates on a mixed control between state and local authorities, but local ordinances must not conflict with the state statutes. Jamal Knight and Bethany Gullman, "The Power of State Interest: Preemption of Local Fracking Ordinances in Home-Rule Cities,” Tulane Environmental Law Journal 28 (2015): 297-314.

This case hinged upon whether the City had preempted state law in its ordinance to ban shale exploration. The Court ruled that the City preempted state law and that the ordinance was conflicting with Article XVI of the Colorado Constitution. COGA v. City of Longmont, No. 13CV63 (Colo. Dist. Ct. July 24, 2014).
} 
from the traditional Native American path of resource development, the Southern Ute Reservation has been able to generate over $\$ 4$ billion in energy revenues (Regan, 2018). ${ }^{9}$ The control over the resource and how it will be allocated on the Ute reservation creates a clearly defined institutional structure that reduces the transaction cost of the institution. This potentially incentivizes firms to extract the resources under the Ute. This institutional structure is one I examine in this paper.

These institutional choices among the levels of formal institutions reflect the importance of transaction costs in deriving development. However, such a design generates variance and balance of interests at each level of government. Thus, I will exploit these choices to explore whether such variation promotes differences in shale development.

\section{B. Permitting Shale on These Institutional Regimes}

Understanding the existing regulations by federal, state, and Native Americans to regulate the exploration of shale is fundamental to establishing institutional choices that potentially generate differences in economic outcomes. In this paper, I will use data on shale wells to act as a proxy for the amount of economic development of shale. To provide a stronger link between this proxy and the institutional variation governing shale extraction, I conclude this subsection with a brief discussion of how this specific institutional variation results in different drill permitting processes. Examining the permitting process directly provides greater granularity to the effect these institutional choices have on participants' incentives with respect to natural resource extraction.

Obtaining a permit on federal, state, and Native American lands is a complex process ${ }^{10}$ that involves many reviews and applications. Despite this complexity, all lands have three essential steps: 1) survey the land and determine if the land is a valuable asset to extract oil and gas; 2) apply for an Application to Drill (ADP); 3) provide a recommendation for reducing concerns for the environment, public interest or other site-specific instances, if such concerns

\footnotetext{
${ }^{9}$ The Southern Ute Native American Tribe is extensively wealthy. Each of its 1,400 members are worth millions and receive dividends from the development within their border. Shawn Regan, Tribal Energy Resources: Reducing Barriers to Opportunity, PERC Report 2018. This stands in contrast to other reservations, which on average and in the U.S. Census data for 2000, "had a real per capita income of $\$ 7,942$ compared with the $\$ 21,587$ for the average U.S. resident; 39 percent lived in poverty compared with 9 percent of white Americans; and the Indian unemployment rate was nearly four times greater than the U.S. average." Indian Energy Development: Hearing Before the Committee on Indian Affairs, 110 ${ }^{\text {th }}$ Cong. (2008) (Statement of Dr. Robert W. Middleton) cited in Maura Groan, Native American Lands and Natural Resource Development. Revenue Watch Institute: 6 (2011).

${ }^{10}$ See appendix for a detailed description of the process on each of these institutional regimes.
} 
arise in the review process. However, the processes depart significantly from one another when considering the level of transaction costs. The costs of exploration on federal lands have significant fees and bonds required prior to any drilling activity. The bond could be as little as $\$ 10,000$ or as much as $\$ 150,000$, but this is dependent upon whether the operation is within one property owned by the BLM or a host of properties owned by the BLM (Bureau of Land Management, 2007). There is also a set of administrative fees for per acre lots on BLM lands ${ }^{11}$ and a royalty payment of $12.5 \%$ for the oil and gas extracted on BLM lands. On state or private lands, there is a significant review processes within the Colorado Oil and Gas Conservation Commission $^{12}$ (COGCC) that present high transaction costs. The operator must submit a financial feasibility statement of their firm and this must be verified by COGCC prior to any administrative processes to obtain a permit. Furthermore, once an ADP has been filed, a review process of 21 to 75 days occurs, where COGCC determines any deficiencies ${ }^{13}$ in the well location. If these deficiencies arise, the operator must present the commission with ways of overcoming them. Afterwards, there is another 21 to 75 days to review the operator's methodology to mitigate the deficiencies in the well site. On the other hand, The Southern Ute has a $\$ 1,000$ fee and a one-time review is conducted by the Southern Ute Department of the Interior. $^{14}$

The institutional choice of these regimes present different transaction costs that incentivize industrial participants to operate with more frequency under the Southern Ute institutional regime. The costs of National Forest Lands and BLM Lands prior to even

\footnotetext{
${ }^{11}$ To acquire BLM land for exploration, the land is auctioned at a land-lease auction by the Bureau. The operator must submit an administrative fee of $\$ 1.50$ per acre and not less than a $\$ 2$ per acre minimum for a bonus bid on these auctioned lands. Once the land is acquired, the BLM requires that the operator pay $\$ 1.50$ per acre for the first five years of the lease and $\$ 2.00$ per acre for the remainder of the lease period, which is another five years. Bureau of Land Management, "General Oil and Gas Leasing Instructions," https://www.blm.gov/programs/energy-andminerals/oil-and-gas/leasing/general-leasing (accessed February 12, 2019).

${ }^{12}$ The statutory authority of the commission is to oversee the oil and gas operations within the State. This authority was established under the Colorado Oil and Gas Conservation Act. Colo. Rev. Stat. \$34-60-100.

${ }^{13}$ Deficiencies could include assessing the well to "ensure impact to the public, environment, and wildlife are minimized". Colorado Oil and Gas Conservation Commission, "Regulatory Process for Permitting and Tracking an Oil or Gas Well", 2019, https://cogcc.state.co.us/documents/about/general/RegProcessPermitandTrackingWell.pdf (accessed October 7, 2018).

${ }^{14}$ This is known as the proposed project notification (PPN) period. During this period, the reservation's Department of the Interior assesses the potential issues with the well and conducts an onsite review. This onsite review is done, in conjunction with the operator, an archaeologist, and biologist, in order to determine the cultural and wildlife impact of the site. Southern Ute Indian Tribe Department of Energy, Exploration \& Production Operator's Manual for Energy Development Projects on the Southern Ute Indian Reservation (2018), https://www.suitdoe.com/wpcontent/uploads/sites/9/2018/07/SUIR-Operators-Manual-June-2018-Update.pdf (accessed October 3, 2019).
} 
attempting a drilling operation present a large fixed cost to firms attempting to drill within this institutional structure. As a consequence, a firm, in attempting to minimize costs, will be less proactive in applying for permits on these lands compared to similar lands, such as the Southern Ute, where these high financial costs are reduced. Furthermore, the long waiting periods of review within COGCC present high transaction costs in concluding the transaction. In a market where the frequency and price of the good is volatile (Smith, 2009), the firm will attempt to maximize their production of the good in the shortest amount of time in order to maximize the profit of shale. However, the cost of concluding the transaction to obtain a permit on state lands, governed under COGCC, could reduce the potential for the firm to maximize its profits. As a result, the firm will choose the Southern Ute, in comparison, because the Southern Ute has a lower transaction cost and accordingly will maximize expected profit realization due to the shorter time and lower volatility to returns to which extraction is subject. The Ute has a lower transaction cost because there is only one review process and it is done in conjunction with reviews of deficiencies in the well site chosen by a firm. The Southern Ute's institutional choices in the permitting process present lower transaction costs compared to neighboring lands. These choices are what I exploit in this paper to demonstrate the empirical affect they have on shale development.

\section{Theory}

To determine the effect of these institutions on shale development, a variation of regression discontinuity is used. This estimation is parallel to Libecap and Lueck (2011), who use a border discontinuity to estimate the effects of land demarcation systems on property rights, land values, and economic growth. This paper employs a similar methodology by testing outside the reservation Public Land Survey System ("PLSS") sections against PLSS sections within the Southern Ute Native American reservation to estimate the effects of these institutions on shale development.

The use of border discontinuity is similar to a regression discontinuity, which estimates treatment effects, where the assigned variable "exceeds a known cutoff point" (Lee \& Leimux, 2010) and has been used to model the persistent effects of a Peruvian extractive institution on contemporary development (Dell, 2010). To employ a regression discontinuity, distances from the known cutoff must be established to accurately estimate the treatment area. However, due to the fact that shale does not lie equally throughout the State of Colorado, imposing this type of 
regression discontinuity will not provide an adequate measure of the institutional effect on shale development. Therefore, this paper will follow Libecap and Lueck's (2011) use of border discontinuity.

\section{Data and Empirical Analysis of Land Institutions and Shale}

This section describes the sample selection process, summarizes the data, and estimates the effects of land institutions on shale development.

\section{A. Sample Regions}

The empirical analysis focuses on one region within the State of Colorado. The region is the San Juan Basin of Colorado. This region encompasses all the respective land institutions found within the United States that allow shale development: Native American, federal, state, and private land. This sample also is one of the most productive shale regions in the Mountain West (Natural Gas Intelligence, 2019). Therefore, this sample is ideal for testing whether institutional choices affect the development of shale.

\section{B. Data}

The data collected is from a series of sources to study the effect of institutions on shale development. Data on the different well types were obtained from the Colorado Oil and Gas Conservation Commission (COGCC), through GIS shapefiles. ${ }^{15}$ This data presents three different types of wells for the state. These include active, plugged, and spudded. ${ }^{16}$ COGCC also provides permit GIS shapefiles, which connects pending and active permits to each well. The data obtained from COGCC provides the variables of interest, which will be used to examine the effect land institutions have on development. The summary statistics of this data are provided in Table 1. To Provide clarity to the wells and permits within the State of Colorado, the data was attached to the Public Lands Survey System's ("PLSS") township and range. Using GIS software, I calculated the total number of wells, spudded, infrastructures present, pending permits, and permits, within each PLSS section. Once the total number of well developments per PLSS section were calculated, a categorical variable, denoting the most prevalent land ownership within each PLSS, was added to each PLSS observation. This allows for a measurable difference in institutions. Furthermore, by using PLSS sections, I am able to provide a spatial link between

\footnotetext{
${ }^{15}$ Data available at: https://cogcc.state.co.us/data2.html\#/downloads. This data is updated as of October 2018. ${ }^{16}$ A spudded well is a well that has begun the initial drilling process, where the drill has been inserted into the ground and cement is added to the drill site to form a barrier to minimize containments from entering the soil and groundwater.
} 
institutions, natural resource development, and other parcel metrics. This allows for a dataset to test institutional choices and their effect on shale development, while also controlling for geological and geographic characteristics that have the potential to impact development.

Table 1: Summary Statistics

\begin{tabular}{|c|c|c|c|c|}
\hline Variable & Definition & Observations & Mean & SD \\
\hline & A. Indian Land & 73 & & \\
\hline Total Wells & All of the wells within a given PLSS section & & 65.95 & 106.28 \\
\hline Spudded Wells & A well that has begun the initial drilling process & & 50.90 & 87.98 \\
\hline Infrastructure Present & $\begin{array}{l}\text { A well pad and other necessary infrastructure that is on a well } \\
\text { site }\end{array}$ & & 15.04 & 24.33 \\
\hline Pending Permits & ADP has been filed & & .34 & 1.66 \\
\hline \multirow[t]{2}{*}{ Permits } & $\mathrm{ADP}$ and Permit has been acquired by the Operator & & .712 & 2.15 \\
\hline & $\begin{array}{l}\text { B. Mixed (More Than One Institutions Governing PLSS } \\
\text { Section) }\end{array}$ & 517 & & \\
\hline Total Wells & & & 13.74 & 64.04 \\
\hline Spudded Wells & & & 8.76 & 42.36 \\
\hline Infrastructure Present & & & 4.98 & 24.92 \\
\hline Pending Permits & & & 3.39 & 22.12 \\
\hline \multirow[t]{2}{*}{ Permits } & & & 1.68 & 13.76 \\
\hline & C. National Forest & 438 & & \\
\hline Total Wells & & & .787 & 4.19 \\
\hline Spudded Wells & & & .600 & 3.38 \\
\hline Infrastructure Present & & & .187 & 1.78 \\
\hline Pending Permits & & & .006 & .14 \\
\hline \multirow[t]{2}{*}{ Permits } & & & .029 & .53 \\
\hline & D. Other (Private and State Lands) & 2,030 & & \\
\hline Total Wells & & & 50.51 & 159.66 \\
\hline Spudded Wells & & & 34.63 & 109.41 \\
\hline Infrastructure Present & & & 15.88 & 61.05 \\
\hline Pending Permits & & & 1.87 & 13.22 \\
\hline Permits & & & 1.75 & 10.54 \\
\hline
\end{tabular}

Figure 1: Counts for the State of Colorado ${ }^{17}$

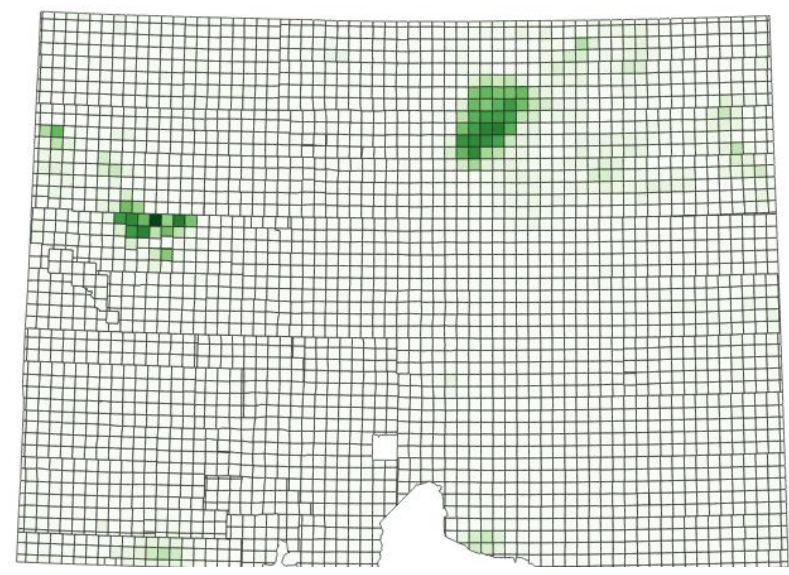

${ }^{17}$ This figure is a gradient in which each PLSS section is assigned a shade depending on the number of wells present. It is on a scale of 33 wells per shade, meaning that the darkest shades have 1630-1663 wells, while the lightest have 0-33. 
Figure 2: Well Count for The San Juan Basin

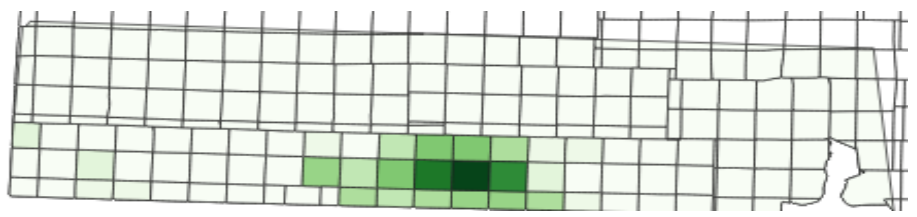

Figure 2 demonstrates the underlying motivation for this question. Figure 2 represents a shaded demonstration of the wells per PLSS section. ${ }^{18}$ The figure indicates that more shale development lies within one specific area of the San Juan Basin compared to the rest of the region. This difference is what I exploit to determine what is the potential mechanism behind this variation. Once Figure 2 is overlaid with the GIS shapefiles containing ownership of lands, the case becomes more prevalent.

Figure 3: San Juan Basin Well Counts and Land Types ${ }^{19}$

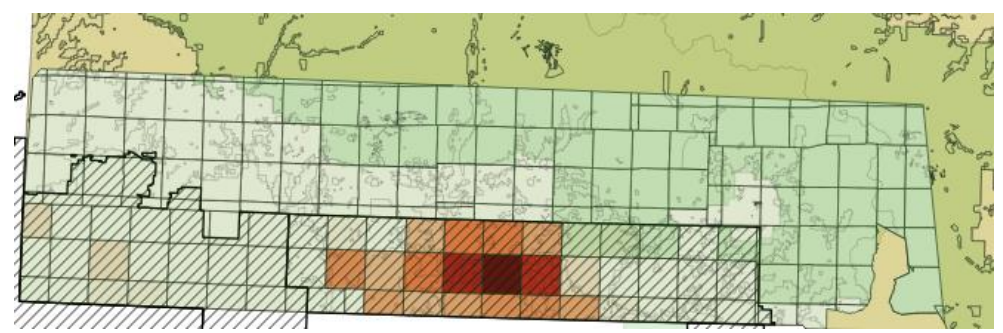

As Figure 3 reveals the development occurs more consistently on Native American lands. I argue that this specific variation is due to institutional factors, which contribute to the current production of shale and potential future development.

\section{Empirical Analysis of Institutions and Shale}

To empirically demonstrate similar results from Figure 3, I analyze the number of shale plays present within PLSS sections. The estimation equation is:

$$
\mathrm{Y}_{i}=\alpha+\beta_{1}\left(\mathrm{Ute}_{i}\right)+f\left(\mathrm{X}_{i}, \mathrm{Y}_{i}\right)+\varepsilon_{i}
$$

$Y_{i}$ represents the outcome variables of interest for observation $i$. These outcome variables of interest are wells, spudded wells, infrastructure present in a well site, pending permits, and permits. The rationale behind using these variables is that they denote different phases of

\footnotetext{
${ }^{18}$ The gradient is broken into segments in which each shade represents 33 wells in each PLSS section. This means that in the lightest shade there are 0-33 wells, while the darkest shade there are 466-499 wells,

19 This figure is analogous to figure 1 but proves the figure by providing land ownership in the region. The black shaded region denotes the Southern Ute Native American Reservation, the yellow shading denotes BLM ownership, the Green represents National Forest land, and the non-shaded regions reflect private or state ownership.
} 
development in extracting shale. In the case of wells, this variable shows current development patterns of extraction. Infrastructure present and spudded wells show the potential for future development and a firm's commitment to extracting the resource on a specific land type due to the transaction costs associated with establishing a well site. Also, permits and pending permits are good measures for understanding the level of transaction costs within an institutional structure due to the fact the procedural process for permitting is defined by the formal rules of a given authority. The $\mathrm{UTE}_{i}$, is the PLSS sections under the Southern Ute reservation and is compared to all other PLSS sections. Lastly, $f\left(\mathrm{X}_{i}, \mathrm{Y}_{i}\right)$ is a control for geographic and geological characteristics that potentially impact the development of shale.

I first estimate $\mathrm{Y}_{i}$ using the larger sample that includes the whole state to gain an understanding of development patterns across the state. The results are provided in Table 4 .

Table 4: Regression Results

\begin{tabular}{|c|c|c|c|c|c|c|}
\hline $\begin{array}{l}\text { Outcome } \\
\text { Variable }\end{array}$ & (1) & (2) & (3) & (4) & (5) & (6) \\
\hline Wells & $\begin{array}{l}29.099 * \\
(12.61)\end{array}$ & $\begin{array}{c}52.01 * * * \\
(14.95)\end{array}$ & $\begin{array}{c}40.83^{* *} \\
(13.21)\end{array}$ & $\begin{array}{l}38.483 \\
(20.60)\end{array}$ & $\begin{array}{l}43.80^{*} \\
(19.34)\end{array}$ & $\begin{array}{l}37.08 * * \\
(15.69)\end{array}$ \\
\hline Spudded Wells & $\begin{array}{l}25.75^{*} \\
(10.37)\end{array}$ & $\begin{array}{c}43.819 * * * \\
(12.07)\end{array}$ & $\begin{array}{c}35.05^{* * * *} \\
(9.56)\end{array}$ & $\begin{array}{l}25.904 \\
(14.00)\end{array}$ & $\begin{array}{l}28.66^{*} \\
(13.62)\end{array}$ & $\begin{array}{l}27.80 * * \\
(10.83)\end{array}$ \\
\hline $\begin{array}{l}\text { Infrastructure } \\
\text { Present }\end{array}$ & $\begin{array}{l}3.35 \\
(2.98)\end{array}$ & $\begin{array}{l}8.189^{*} \\
(3.91)\end{array}$ & $\begin{array}{c}5.79 \\
(4.74)\end{array}$ & $\begin{array}{l}12.579 \\
(7.49)\end{array}$ & $\begin{array}{l}15.14^{*} \\
(6.60)\end{array}$ & $\begin{array}{l}9.65^{*} \\
(4.8)\end{array}$ \\
\hline Pending Permits & $\begin{array}{c}-1.522 * * * \\
(0.33)\end{array}$ & $\begin{array}{l}0.306 \\
(0.23)\end{array}$ & $\begin{array}{l}0.001 \\
(0.23)\end{array}$ & $\begin{array}{l}0.282 \\
(0.42)\end{array}$ & $\begin{array}{c}0.39 \\
(0.46)\end{array}$ & $\begin{array}{l}.112 \\
(.111)\end{array}$ \\
\hline Permits & $\begin{array}{c}-0.78 * * * \\
(0.31)\end{array}$ & $\begin{array}{l}0.511 \\
(0.40)\end{array}$ & $\begin{array}{l}0.644 \\
(0.31)\end{array}$ & $\begin{array}{l}1.183 \\
(0.73)\end{array}$ & $\begin{array}{c}1.32 \\
(0.85)\end{array}$ & $\begin{array}{l}.535^{* *} \\
(0.222)\end{array}$ \\
\hline Observations & 3,058 & 103 & 62 & 62 & 62 & 62 \\
\hline $\begin{array}{c}\text { Statistical } \\
\text { Significance }\end{array}$ & $\begin{array}{c}* \mathrm{p}<0.05 \\
* * \mathrm{p}<0.01 \\
* * * \mathrm{p}<0.001\end{array}$ & & & & & \\
\hline
\end{tabular}


The results in column 1 in Table 4 confirm the information provided from Figure 1. Column 1 shows that there is considerable variation in wells throughout the state. On average, there are 329 more wells in each PLSS section within the Southern Ute compared to the rest of the state. This regression shows an important finding that verifies the mechanism of property rights development discussed earlier. A variation of 3-29 more wells in PLSS sections under the Ute, which is one-square mile, compared to the rest of the state, is an extensive amount of natural resource development for a region. Such an amount of natural resource development and the relative scarcity of the resource incentivizes participants and political actors to define the rights to the allocation of the resource. This is consistent with the arguments made for how rights to a natural resource are established. The formation of these rules leads to an expected value increase in the asset and provides a further incentive to define the rights to the extraction of the resource. ${ }^{20}$ I argue that this mechanism is present within the State of Colorado. However, the results provided in column 1 do not control for all the potential variation that could explain this difference in development on the Ute compared to neighboring lands. As a result, I build upon these results in columns 2-5 to minimize the variation that exists in causing this difference in development.

The results from column 1 demonstrate that shale development is extensive within the Southern Ute and that such an amount of development potentially provides the incentive for institutional rules to be establish that promote the extraction of the resource. The results in column 2 builds on column 1 by limiting the sample to the San Juan basin. I explicitly limit the sample to the PLSS sections within the San Juan Basin. I restrict the sample to this region because shale does not lie consistently throughout the state. The results are provided in column 2 of Table 4.

The results in column 2 demonstrate that the Southern Ute reservation is a very productive area within the San Juan Basin. On average, there are 52 more wells on the Southern Ute compared to other PLSS sections within the San Juan Basin. This amount of development presents a similar rationale provided by the results in column 1 . However, similar to the results in column 1, the results in column 2 do not minimize the variation that exists in explaining the

\footnotetext{
${ }^{20}$ Anne-Sophie, Brasselle, Frédéric Gaspart, and Jean-Philippe Plateau, "Land Tenure and Security and Investment Incentives: Puzzling Evidence from Burkian Faso," Journal of Development Economics 62 (2002): 373-418; Simon Johnson, John McMillan, and Christopher Woodruff, "Property Rights and Finance," American Economic Review 95 (2002): 1335-1356.
} 
difference in development but do demonstrate that the San Juan basin is a proper sample to examine institutional choices on the development of shale.

These results also demonstrate an important consideration in restricting the sample to the San Juan Basin. In the results from column 1, the number of permits and pending permits, on average, were negative on the Ute lands compared to the rest of the state. This was due to the fact that there were more PLSS sections with no shale development and no permits. This skewed permits and pending permits towards a negative coefficient. By limiting the sample to the San Juan Basin and the PLSS sections within the region experiencing some amount of development, I can accurately estimate these outcome variables. Thus, the prediction of permits in results column 2, as well as columns 3-6, are better representations of the data.

The previous columns of results show that the Southern Ute experiences an extensive amount of shale development compared to both the whole state and the San Juan Basin in particular. I argue that this amount of development is due to the fact that policymakers and participants of the Ute have defined their institutions in such a way that facilitates the production of shale. Furthermore, the previous results display why restricting to the San Juan Basin provides precise estimates for the outcome variables of interest. However, these previous results fail to casually link institutions to the development of shale. The results in column 3 are from a border discontinuity research design and it estimates the effect of these institutions on shale development. Limiting to PLSS sections within the border regions of the Ute, I estimate the effect of institutions governing property on shale development. This regression equation imposes an added condition of only testing PLSS sections on either side of the Ute border within onesquare mile. This estimates the difference in development between being directly within the Ute and directly outside the Ute. These results are provided in column 3 in Table 4.

The use of border discontinuity demonstrates that being on the Ute has, on average, 40 more wells compared to non-Ute PLSS sections directly across the border of the reservation. These estimates are statistically signficiant at the 0.01 percent level. These results strongly minimize the potential for factors beyond the institutional choice to effect shale development. The increase in the number of wells within one PLSS section of the Ute compared to one PLSS section beyond the Ute suggests that factors beyond geographic and geological differences are driving this change in development. This is the case because by limiting to only the border regions of the Ute, I minimize the potential for geological factors to contribute to the difference 
in development. Therefore, this difference is much more likely to be due to institutional differences of the Ute reservation presenting lower barriers to the use of shale rights, which provides the incentive for extraction to occur within the reservation and not on the neighboring lands. However, the results provided in column 3 do not explicitly control for geological differences and these differences may still influence the difference in shale development. I present explicit controls of geological differences in results columns 4 and 5 to rebut claims that geological variation may still be impacting this development pattern.

The results in column 3 provide strong evidence that the institutional arrangements governing land types are a major factor in determining shale development within the San Juan Basin. The results in column 4 build upon this evidence by controlling for latitude and longitude, which act as proxies for the geological variation that may influence these results. Using latitude and longitude, I provide a control that captures the variation in geological characteristics that flow continuously over the San Juan Basin that may influence the discrete change in the institutional boundary of the Southern Ute. This limits the impact that the geological differences might have on empirically observable shale development. The control is a popular approach when attempting to control for variables that are related to geography and vary smoothly over the geographic area. It has been used to control for factors influencing the change in demarcation systems (Libecap \& Lueck, 2011). ${ }^{21}$ The results are shown in Table 4.

The results in column 4 show that once controlling for geological differences, the Ute has, on average, 38 more wells compared to neighboring PLSS sections across the reservation border. The estimates lost statistical significance when controlling for latitude and longitude. This change in statistical significance would be suggestive that geological differences play a factor in affecting shale development. However, the minimal change in magnitudes from the results in columns 3 and 4 show that this is not the case. The results in column 3 report that there are 40 more wells on the Ute compared to neighboring lands, while the results in column 4 report 38 wells more wells on the Ute. This is a two well decrease per one-square mile in a region, where, on average, there are 65 wells per one-square mile. This magnitude change is not large enough to conclude that the variation in development is due to geological differences. These

\footnotetext{
${ }^{21}$ Admittedly, this approach suffers from not being able to control for the geological differences in shale that vary discontinuously; however, it is the most widely used control when using geographic data, such as this dataset, that I move forward with this method, while noting its apparent weaknesses.
} 
estimates strongly suggest that geological differences are a minimum factor in influencing well development. Minimizing the variation in all possible factors contributing to the variation in shale development and still estimating discontinuous development, suggests that the institutional choice of the Ute is a determining factor in shale development. I expand upon this evidence by employing an estimation for controlling for geological differences that might not lie smoothly across the sub-surface of the earth.

The results in column 4 control for the possibility of geological differences causing the variation in shale development between the Southern Ute and neighboring lands. The results in column 5 build upon this argument by using the polynomial of latitude and longitude.

Controlling for the geological difference by using the polynomial of latitude and longitude, I use a nonlinear and discontinuous function to control for the geological differences that might vary discontinuously. Using the polynomial of latitude and longitude is an estimation technique used in Dell (2010), where data requirements restrict the use of nonparametric estimations and a semiparametric estimation must be used. ${ }^{22}$ The regression results are provided in Table 4.

Controlling for the polynomial of latitude and longitude, there are still more wells on the Ute compared to neighboring lands. Column 5 shows that for the dependent variable wells, there are 43.80 more wells on the Ute compared to neighboring lands. Column 5 shows that for the dependent variable spudded wells there are 28.66 more spudded wells on the Ute compared to neighboring lands. Column 5 shows that for the dependent variable well infrastructures there are 15.14 more well infrastructures on the Ute compared to neighboring lands. All measures of well development are statistically significant at the five percent level. This suggests, once controlling for continuous and discontinuous variation in geological differences, developmental differences still exist. Conversely, the results in column 5 show that for pending permits and permits there is a strong case for future development patterns in the Southern Ute reservation. Column 5 reports 1.183 more permits and 0.39 more pending permits on the Ute compared to non-Ute PLSS sections. These magnitudes are significantly above the average among permits and pending permits within the San Juan Basin overall. This is strongly suggestive that the institutional choices of the Southern Ute present lower costs to firms such that future production is more

\footnotetext{
${ }^{22}$ A critique of this estimation is that I may over-fit at the border of the Southern Ute. However, there is no a priori rationale to why using this polynomial function of latitude and longitude is a good control for these differences. Nonetheless, I use this estimation to be consistent with scholars using regression discontinuity estimations and geographic data.
} 
likely predicted on the Ute compared to neighboring lands. Due to the level of controls for confounding variables, the results provided in column 5 are the preferred model and suggest that institutions are directly creating this difference in shale development.

\section{Robustness Check: Poisson Distribution}

This model uses OLS in the border discontinuity. This provides a strong case for institutional choices affecting shale development within the San Juan Basin. To provide further robustness to this assertion, I alter the OLS assumption to a Poison model. ${ }^{23}$ The data on well development within a PLSS section is a non-negative integer. Therefore, adjusting the assumption to a Poison model offers more flexibility in the specification compared to the OLS because a Poison model is intended to model count data. The robustness check will provide further evidence to the assertion made by the results provided in the border discontinuity controlling for the polynomial of latitude and longitude. The results for this robustness check are provided in column 6 in Table $4 .^{24}$

The results from this robustness check affirm the results from the robust results of column 5. Once accounting for the dependent variables being non-negative integer values, the difference in shale development still exists. In fact, column 6 for the dependent variable wells reports estimates of a marginal effect of 37 more wells on the reservation, an estimate which is statistically significant to the 0.01 significance level. Column 6 for the dependent variable spudded wells reports estimates of a marginal effect of 27 more spudded wells on the reservation, an estimate which is statistically significant to the 0.01 significance level. Column 6 for the dependent variable infrastructure present reports estimates of a marginal effect of 9 more infrastructures on the reservation, an estimate which is statistically significant at the 0.05 significance level. Column 6 reports an increased marginal effect on the Ute compared to neighboring lands for both pending permits and permits. Column 6 for the dependent variable permits reports estimates of a marginal effect of 0.56 more permits on the reservation, an estimate which is statistically significant at the 0.01 significance level. The robustness check demonstrates that even altering the assumption of normal distribution to a poison distribution, there is a positive marginal effect on shale development by being within the Southern Ute Native

\footnotetext{
${ }^{23}$ An objection to this model is it assumes equality of mean and variance and may be less reliable in a heterogenous sample, such as this sample. A negative binomial specification would provide more flexibility in the specification of the variance. I ran both these models and there was no marginal difference in the estimates of the two models.

${ }^{24}$ Column 6 reports these estimates in the marginal effect of being in the Ute by using the STATA command mfx.
} 
American Reservation. This robustness check provides additional compelling evidence that the institutional structure of the Southern Ute is causing more development to occur within reservation lands compared to neighboring lands governed by different institutions.

The identification assumption in this model is that the Southern Ute Native American Reservation is randomly assigned with respect to shale development and that the random assignment of boundaries does not otherwise corelate with other factors to be determinate of shale deposits. Without this assumption, I cannot conclude there is a causal link between institutions and development. The preferred estimation equation of the border discontinuity regression controlling for the polynomial of latitude and longitude is as good as a random assignment in an ideal world. This preferred estimation is as good as the ideal random assignment because restrictions of the sample to the State of Colorado, the San Juan Basin, the border PLSS sections of the Ute, and controlling geological characteristics minimizes the potential error in the many driving factors of difference in shale development. In this restriction of sample and controls, statistically significant differences in development are still observed. As a result, my most robust results provide compelling evidence that the mechanism of institutional choices are driving this difference in shale development. The Southern Ute Native American Reservation experiences more shale development compared to neighboring lands. Indeed, even when controlling for geological differences that vary smoothly and discontinuously across the border regions of the Southern Ute, there is still a difference in the number of wells between the Ute lands compared to the neighboring lands.

\section{E. Discussion}

The preferred estimation results highlight the fundamental role these institutional choices play in the development of shale. On every aspect of development, from the permitting process to the actual extraction of the resource, institutional choice matters. The Southern Ute experiences more shale development compared to neighboring lands because the Ute deliberately chose to foster economic development through their institutional choices over the governance of shale. The Ute has established more localized control over the resource by reducing the transaction costs within the development process of shale. This localized control over the resource allows the Ute to establish rights to the resource that aid in continued economic growth of the resource. Furthermore, by establishing more specified and enforceable property rights, there is a greater protection to the underlying asset of shale. This, in return, provides an incentive 
for firms to invest under this institutional structure and is clearly shown by the amount of permitting that takes place on the Ute.

Institutional choice can thus greatly influence the cost of shale operations. As Ronald Coase (1960) noted, the cost of concluding these transactions to permit shale are often determined by the institutions governing the process and are significant, which can influence the frequency of transactions within the market of shale development. By creating institutional rules that reduce the costs of concluding a shale transaction, the Ute has influenced the magnitude and frequency that these transactions occur; thus, more shale development on their lands compared to neighboring institutions.

Furthermore, the findings highlight a tangible policy implication. The State of Colorado's Senate has proposed a bill ${ }^{25}$ that would fundamentally alter the Colorado Oil and Gas Conservation Commission and local jurisdictional powers. ${ }^{26}$ The proposed bill would restructure COGCC's statutory authority of natural resource development and protection of private property to directly regulating the industry and protecting the environment. ${ }^{27}$ The bill would also establish that every industrial participant must provide a financial assurance account for each new and existing well within the state. ${ }^{28}$

\footnotetext{
252019 Bill Text CO S.B. 181: Protect Public Welfare Oil and Gas Operations: Concerning additional public welfare protections regarding the conduct of oil and gas operations. Doi: https://leg.colorado.gov/bills/sb19-181. ${ }^{26}$ The proposed legislation would allow local jurisdictions to "regulate lands use to oil and gas operations, including specifically the sitting of an oil and gas location." 2019 Bill Text CO S.B. 181. This would directly impact firm's incentives in counties where private and state land is prominent. It would force a restructure of development towards less costly institutional regimes, such as the Southern Ute reservation. Given the fact that the analysis provided here focuses on a basin where more national forest is prevalent in the comparison, I cannot provide empirical estimates to how this change in local jurisdictional power would alter development, but it would alter development in some manner. Furthermore, the proposed legislation would generate significant litigation on the question of home-rule and whether the matter shale development is of local concern, where home-rule supersedes state law. Ryals v. City of Englewood, 2016 CO 7, P.3d 900; Winslow Constro. Co. v. City \& Cty. Of Denver, 960 P.2d 685,693-95 (Colo. 1998) or whether the matter is a statewide, mixed state, and local concern, in which case state law supersedes homerule ordinances. Ryals 364 P.3d at 905; Webb 295 P.3d at 486. These issues are also determined on a case-by-case basis. Webb 19, 295 P.3d at 486-87; accord Ryals 13, 364 P.3d at 905.

${ }^{27}$ The bill would change the language of the statute authorizing the intent of COGCC from: "foster the responsible, balance development, production, and utilization of natural resources of oil and gas in the State of Colorado in a manner consistent with protection of public health, safety, and welfare, including protection of the environment and wildlife resources" to "regulate the development of natural resources of oil and gas in the State of Colorado that protects public health, safety, and welfare including protection of the environment and wildlife resources." 2019 Bill Text CO S.B. 181. (emphasis added).

${ }^{28}$ In attempting to obtain a permit, an operator now must "apply for a permit to drill, which must include proof either that the operator has filed an application with all affected local governments to approve the sitting of the proposed oil and gas location and the local government's disposition of the application; or no affected local government regulates the sitting of oil and gas locations." 2019 Bill Text CO S.B. 181. (emphasis added). It would also establish that the commission would require every operator to "provide assurance that it is financially capable of fulfilling every obligation imposed by this Article $60 \ldots$ The Rule-making must consider: increasing financial
} 
My analysis provides a telling estimate of the impact of these institutional changes on shale development. Although the bill's sponsor claims its intent is to restructure where the development occurs and not necessarily decrease shale development all together, ${ }^{29}$ others contend that the intent is to decrease development throughout the state. ${ }^{30}$ Regardless, of the intent underlying the legislation, my analysis suggests that this proposed bill, if passed, will become an expression of "Not-in-my-backyard" (NIMBY) in practice. ${ }^{31}$ My analysis further

assurance for inactive wells and for wells transferred to a new owner; requiring a financial assurance account, which must remain tied to the well in the event of a transfer of ownership, to be fully funded in the initial years of operation for each new well to cover future costs to plug, reclaim, and remediate the well." 2019 Bill Text CO S.B. 181. (emphasis added).

${ }^{29}$ Senator Fenberg, the sponsor of the bill, speaking on behalf of the statutory intent of the proposed bill: "Probably only a handful of cities and counties, who will use this land use authority, and have additional regulations on top of what the state regulations are and will be. Those cities and counties, I would argue, are probably the ones that are currently that don't have that much oil and gas activity in them. Such as, let's say Boulder county. They will probably use this land use authority and they will have additional regulations. These regulations are not going to have much of an economic or job impact in those places that don't currently have much oil and gas drilling. You can't reduce jobs from zero. I believe there are areas that want oil and gas extraction that are friendly to it, will probably not have stricter regulations on their books than what the state has and those operators and operations will continue because it is important to that communities economic base and their values." Hearing on 2019 Bill Text CO S.B. 181 in the Senate Committee on Transportation and Energy (2019) (Statement of Senator Stephen Fenberg, Majority Leader).

30 "As written, SB181 threatens the future of the energy industry and economic growth and sustainability of our Colorado families... Additionally, Senate Bill 181 could effectively create an oil and gas ban, which would destroy the bipartisan efforts of our former governor, both U.S. Senators, congressmen and many western Colorado counties made to promote the Jordan Cove project, a liquefied natural gas export facility in Coos Bay, Oregon that will allow natural gas to be extracted in western Colorado." Rose Pugliese, "Demand State Lawmakers to Reject Senate Bill 181", The Daily Sentinel, Mar. 14, 2019. Doi: https://www.gjsentinel.com/opinion/columns/demand-statelawmakers-to-reject-senate-bill/article_53a80696-45f0-11e9-8e3d-20677ce85d90.html; "This bill would dangerously curtail new oil and gas development, eliminate tens of thousands of jobs, decrease much-needed Colorado tax revenue and eliminate the bulk of the savings residents and businesses have seen in energy costs in recent years." "Consumer Energy Alliance: SB 19-181 an Economic Killer for Colorado Families, Business", Associated Press, March 13, 2019 Doi: https://www.apnews.com/Business\%20Wire/e8a365043c6b4c7c9953a6e0880b1ee2; "On [March 4, 2019], the Colorado Republican Committee released a statement calling SB 181 "crushing legislation that will devastate Colorado's energy industry'... [Tracee Bentley, Executive Director of the Colorado Petroleum Council] said she was concerned about "unintended consequences" of the bill and she said she believes that it sets up a "possible moratorium situation or a scenario where we can't develop." Jennifer Kovaleski and Nicole Brady, "Bill Overhauling Oil and Gas Regulation gets First Hearing Tuesday After Competing Rallies, The Denver Channel, March 5, 2019 Doi: https://www.thedenverchannel.com/news/local-news/bill-overhauling-oil-and-gas-regulationgets-first-hearing-tuesday.

31 "Is a term used to describe the reaction of local homeowners who object to further development within their community, fearing that such development might reduce the market value of their homes or change the character of the community." Patricia E. Salkin \& Ashira Pelman Ostrow, Cooperative Federalism and Wind: A New Framework for Achieving Sustainability, 37 Hofstra L. Rev. 1049, 1052 (2009) cited in Emeka Duruigbo, Fracking and the Nimby Syndrome, 26 N.Y.U Envtl. L. J. 227 (2018). A NIMBY policy tends attempt to produce similar results in other communities. Ibid. See also Orlando E. Delogu, NIMBY is a National Environmental Problem, 35 S.D.L. Rev. 198 (1990). Delogu explores similar undesirable consequences of NIMBY policies, "Town A's action are frequently replicated in towns $\mathrm{B}$ and $\mathrm{C}$ making it impossible for some activities to find any situs in whole states. The need for the unwanted activity or facility does not go away and consequently, land needs for such facilities 
suggests that implications result from this NIMBY policy choice. The institutional variation created by the home-rule will produce jurisdictional competition. In counties where objections to fracking are on the basis of environmental concerns, property values ${ }^{32}$ and scenery, ${ }^{33}$ these counties will ultimately ban the exploration of shale. Such a choice by counties and local jurisdictions will make it extremely difficult for shale operators to obtain any state or private lands for exploration. Operators will likely end up extracting more on the Southern Ute Reservation because the Ute institutions will further encourage shale development, in a relative sense, in the event other communities use home rule to ban shale exploration. If the intent of the bill is to reduce shale development within the state, this jurisdictional variation will ultimately cause the bill not to have its intended effect. Conversely, the economic demand for shale will not decrease due to the passage of this bill. The bill would only decrease the supply of available lands for development and will more likely increase demand for those lands that would allow continued development. The increase in demand for these lands will result, on the margin and to the extent to which closing wells in one location is viable, in the Ute experiencing comparatively more development. My analysis suggests that Senate Proposed Bill 181 will likely not have its intended effect and will ultimately cause jurisdictional competition resulting in comparatively more development on the Southern Ute Native American Reservation.

The findings underscore the importance of property rights and transaction costs, and accordingly results in tangible policy implications within the state of Colorado. The results show how institutional rule sets that promote the protection of private property by providing more certainty to the right to extract shale lead to more shale development. The results also indicate that if an institutional structure can have lower transaction costs compared to other institutional

grow more acute as they supply of spaces for these undertakings dwindles in the face of steady (or more likely, increasing) demand. The NIMBY rejection of land using activities and facilities that responsibly handle unwanted but essential societal needs forces these needs to be met in a variety of irresponsible ways that almost always pose greater dangers to the environment and the larger society than the dangers or risks associated with the proposed, but rejected, activity, or facility." Ibid. at 201

32 See Emeka "When a segment of the population in a particular area would be the prime beneficiary of a project in that area, neighbors, who would not receive any or nearly the same level of benefits, while bearing a sizeable amount of the burden from the development, are likely to oppose the project using the NIMBY argument as a tool" Ibid. at 247 Furthermore, contrary to NIMBY concerns, placing a ban on fracking activities can actually hinder property values. See Morgan D. Rosalie, What The Frack?: An Empirical Analysis of the Effect of Regulation on Hydraulic Fracturing, 16 Quinnipiac Health L. J. 77, 108 (2013).

${ }^{33}$ This has been shown to be a NIMBY objection in "affluent and political savvy communities, [who] are able to utilize those campaigns to promote their own interest, ensuring continued protection of their property values and scenery" See Emeka, Ibid at 245. 
structures the frequency of shale firms within the structure will increase, resulting in more shale development. Lastly, the results have clear implications for the proposed Colorado Senate bill which would broadly change the institutions governing shale exploration within the state. The institutional change would adversely cause developmental differences of shale across the State of Colorado and result in more development within the Southern Ute.

\section{Conclusion}

Institutional design choices over the governance of land use directly affect the economic development of a region. In the context of western lands, the use of localized control, collective enforcement, and better specified and enforceable property rights aids in the economic growth of the region. Native American lands typically have not experienced a similar development pattern. However, the Southern Ute stands as an exception to this pattern due to having established a greater ownership of their use of natural resources. Furthermore, the current institutional choices by the federal government, states, and local jurisdictions have created considerable uncertainty in understanding the extent to which institutional structure governs the extraction of shale. This complex variation of institutional rule sets is demonstrated by the process of shale permitting, where federal land ownership experiences high transaction costs to obtaining a permit. The State of Colorado land also presents similar costs to shale developers. However, the Ute has established a permitting process that reduces these costs. These differences in institutions create empirically observable disparities in shale development within the State of Colorado. In using GIS data and a border discontinuity research design, I provide compelling evidence that the Southern Ute reservation has more shale development compared to neighboring lands. This is due to the fact that the Southern Ute has institutional design choices that promote the use of localized control and more specified and enforceable rights to shale, which reduces transaction costs. This, in return, increases the frequency of transactions and extraction of shale development within the Southern Ute Native American Reservation.

This study of institutions and shale development makes a number of contributions relevant to scholars and policymakers. The role of property rights within an institutional structure can directly impact whether one region experiences more development than a neighboring region. The institutional variation that exists in governance of natural resources presents different levels of transaction costs, which force industrial participants to select the lowest transactional cost institutional design when deciding strategies for the extraction of shale. Also, a change in an 
institutional structure to the level of protection to private property and an increase in transaction costs will directly led to a decrease in natural resource development. This analysis is strongly suggestive that institutional variation creates development displacements that may hinder the intended purpose of regulations restricting development under one structure. Ultimately, this study adds to the empirical evidence that institutions matter in determining the economic development of a natural resource. 


\section{Appendix}

1. Detailed process of obtaining a permit on National Forest, BLM, State land, and Southern Ute Native American Land

In the case of federal lands, two regulatory processes occur depending on whether the status of the underlying land is owned by the Bureau of Land Management (BLM) or The National Forest Service. If the land is BLM, the BLM is the primary institution governing the process. If a particular resource deposit is found upon National Forest lands, the Forest Service, under the Federal Onshore Oil and Gas Leasing Reform Act of 1987 (30 U.S.C. §181 et. seq), determines whether the lands can be opened for exploration. However, the Forest Service participates with the BLM in managing the resources and approving drilling permits on National Forest Lands. This results in the BLM approving permits on National Forest Lands, as well as BLM Lands. An operator begins the process with either a notice to survey or a direct application to drill (ADP). Under a notice to survey, the process is the same as the ADP process, but produces faster approval of the final permit. In either case, an ADP must be submitted. In submitting an ADP, the application must include: "surface use plans, a drilling plan, a well plat certified by a registered surveyor, evidence of bond coverage, operator certification, and other information required by notice or regulation" (Bureau of Land Management, 2007). After the ADP is submitted, the operator has 10 days to coordinate with the BLM to schedule an onsite inspection (Bureau of Land Management, 2007). This onsite inspection will determine the "impact of the drilling on environmental, public, and site-specific concerns" (Bureau of Land Management, 2007). If stipulations arise, the operator must present strategies to overcome the stipulations. Furthermore, the operator must fulfill a bond for the operations. This bond is set at a minimum of $\$ 10,000$ for statewide operations and $\$ 150,000$ for nationwide operations (Bureau of Land Management, 2007). The bond amount may be subject to increases if the BLM discovers "a history of violations, uncollected royalties, number of wells, age of the field, environmental issues, right of way costs or to cover losses to human health within the operator or the site in which the operator is petitioning to extract" (Bureau of Land Management, 2007). Also, the bond may be subject to an increase to protect the owner in split-estates. (Bureau of Land Management, 2007). This is when the surface and sub-surface ownership are under two different parties. For example, a private landowner, who has sub-surface rights to the BLM land neighboring his land. Under this ownership, mineral rights take precedence over other rights and 
applies (BLM, Leasing and Development of Split Estate, 2019). This public policy has origins in the Stock Raising Homestead Act of 1916 (43 CFR §3814).

Furthermore, the BLM will issue auctions of oil and gas leases on strictly BLM Lands. These auctions are quarterly and occur whenever lands are available for leasing. The auctions take two forms, competitive and non-competitive. Competitive auctions are designed for newly opened lands, while non-competitive auctions are on lands that have been auctioned previously but failed to receive a bid. In order to participate in these auctions, a lease bid form must be filed, which requires an administrative fee, equal to the first year's advance of the land $\$ 1.50$ per acre and not less than \$2 per acre minimum for a bonus bid (Bureau of Land Management, 2019). Once a bid has been accepted, the operator may enter the lands to survey, in which case it enters the process of obtaining an ADP, as with National Forest lands. Once the ADP is accepted on BLM lands, the operator must pay a $\$ 1.50$ per acre for the first five years of the lease and $\$ 2.00$ per acre for the remainder of the lease period, which is another 5 years. Also, these lands collect a $12.5 \%$ royalty on all oil and gas extracted from the lands (Bureau of Land Management, 2019).

The State of Colorado permitting process is directed by the Colorado Oil and Gas Conservation Commission (COGCC) and established under the Colorado Oil and Gas Conservation Act (Colo. Rev. Stat. §34-60-100). Under COGCC regulations, prior to obtaining a permit, an operator must register their operation under Form 1. This form determines the financial feasibility of the request and whether the operator is valid by having an operator number (Colorado Oil and Gas Conservation Commission, 2019). Depending on whether the request is filed by a primary operator or is acting as an agent for another, Form 1A might be needed to fill this request. Once an operator has been verified, a financial assurance or bond must be applied to the request and is required prior to any operations on the land in question. This bond is then vetted through the staff at COGCC to determine whether the financial assurance is valid and there are no time requirements for this process by statute or regulation. When the bond is accepted, an application to Permit to Drill, Deepen, Recomplete, Re-enter, and operate (ADP) must be filed. This review process cannot be approved in less than 21 days and the operator can request a hearing if the request has not been fulfilled in 75 days (Colorado Oil and Gas Conservation Commission, 2019). When an operator obtains an ADP, a location assessment of the site will be conducted to "ensure impacts to the public, environment, and wildlife are minimized" (Colorado Oil and Gas Conservation Commission, 2019). In this review process, any 
deficiencies in the environment or public interest are recognized, the operator will be notified and within 30 days notify COGCC of their strategy to mitigate these concerns. Similar to an ADP, this process can take 21-75 days and after 75 days the operator can request a hearing. At this point in the process, an operator has obtained a permit to drill.

Native American land, specifically the Southern Ute Native American Reservation, follows five major procedures to obtaining a permit to drill. Prior to the permitting process, a firm will need to determine whether its operation will be "on-lease" or "off-lease", meaning whether the site itself or the use of minerals will be tribally owned. The answer to this question determines which authority will govern drilling subsequently. In the case of on-lease processes, the tribal government takes a fundamental role, with minimal state and federal government involvement. Once determining operational types, a permission to survey must be obtained. If the permission is granted through tribal consent, the operator will be allowed to survey the land and the application will be valid for two years. Once a survey is conducted, it must be submitted to the Southern Ute's Department of Energy with a host of specific information including: well location, reference stakes, and pad dimensions (Southern Ute Indian Tribe Department of Energy, 2018). After submission of the survey, the proposed well will enter a proposed project notification (PPN), where the tribal Department of the Interior will assess the potential issues with the proposed well. The approval of a PPN will send the proposed well into an onsite review, where the operator will be charged a $\$ 1,000$ fee and have an outside archaeologist and biologist assess the cultural and wildlife impact of the site (Southern Ute Tribe Department of Energy, 2018). Once approved, the operator must obtain a permit to drill (APD) and comply with NEPA regulations. Lastly, prior to disturbing the ground, the operator must give a five-day notice of the intent to drill. These procedures to drill on the Southern Ute ensure the development of the resource, while taking into consideration other factors. The Ute also is the "lead [institution] in managing hydraulic fracturing and chemical disclosure on tribal trust lands" (Southern Ute Tribe Department of Energy, 2018). 


\section{References}

Alston, Eric and John Stafford. "Muddying The Waters: Sixty-One Years of Doctrinal Uncertainty in Montana Water Law." Brigham-Kanner Property Rights Conference Journal 7 (2018): 155-184.

Alston, Lee J., Edwyna Harris and Bernado Mueller. “The Development of Property Rights on Frontiers: Endowments, Norms, and Politics.” Journal of Economic History 72 no.3 (2012): 741-770.

Acemoglu, Daron, Simon Johnson, and James A. Robinson. "The Colonial Origins of Comparative Development: An Empirical Investigation.” The American Economic Review 91 no. 5 (2001): 1369-1401.

Acemoglu, Daron, and Simon Johnson. "Unbundling Institutions." Journal of Political Economy 113, no. 5 (2005): 949-995.

Ambler, Marjane. Breaking The Iron Bonds: Indian Control of Energy Development. (Univeristy Press of Kansas, 1990).

Anderson, Terry, and Dean Lueck. "Land Tenure and Agricultural Productivity on Indian Reservations.” Journal of Law and Economics 35 no.2 (1992): 427-454.

Anderson, Terry and P.J. Hill. The Not So Wild Wild West: Property Rights on the Frontier. (Stanford Univeristy Press, 2004).

Brasselle, Anne-Sophie, Frédéric Gaspart, and Jean-Philippe Platteau. "Land Tenure and Security and Investment Incentives: Puzzling Evidence from Burkian Faso.” Journal of Development Economics, 68 (2002): 373-418.

Bureau of Land Management, “General Oil and Gas Leasing Instructions,” 2019, https://www.blm.gov/programs/energy-and-minerals/oil-and-gas/leasing/general-leasing (accessed February 12, 2019).

Bureau of Land Management, "Leasing and Development of Split Estate,” 2019, https://www.blm.gov/programs/energy-and-minerals/oil-and-gas/leasing/split-estate (accessed February 12, 2019).

Bureau of Land Management, "Surface Operating Standards and Guidelines for Oil and Gas Exploration and Development: The Gold Book," 2007, https://www.blm.gov/sites/blm.gov/files/Gold\%20Book\%202007\%20Revised.pdf (accessed February 12, 2019). 
Coase, Ronald. "The Problem of Social Cost." Journal of Law and Economics 3 (1960): 1-44.

COGA v. City of Longmont, No. 13CV63 (Colo. Dist. Ct. July 24, 2014).

Colo. Rev. Stat. §34-60-100.

Colorado Oil and Gas Conservation Commission et. al. v. Martinez et. al., No.12SC297 (CO. 2019).

Colorado Oil and Gas Conservation Commission, "Regulatory Process for Permitting and Tracking an Oil or Gas Well”, 2019, https://cogcc.state.co.us/documents/about/general/RegProcessPermitandTrackingWell.pd $\underline{f}$ (accessed October 7, 2018).

"Consumer Energy Alliance: SB 19-181 an Economic Killer for Colorado Families, Business", Associated Press, March 13, 2019, https://www.apnews.com/Business\%20Wire/e8a365043c6b4c7c9953a6e0880b1ee2 (accessed March 17, 2019).

Cherokee Nation v. Georgia, 30 U.S. (5 Pet. 1 (1831)).

De Soto, Hernando. The Mystery of Capital. (New York: Basic Books, 2000).

Dell, Marrisa. "The Persistent Effects of The Mining Mita." Econmetrica 78(6) (2010): 18631903.

Delogu, Orlando E. "NIMBY is a National Environmental Problem.” 35 S.D.L. Rev. 198 (1990).

Demsetz, Harold. "Property Rights." The American Economic Review 57 no.2 (1967): 347-359.

Duruigbo, Emeka. "Fracking and the Nimby Syndrome." 26 N.Y.U Envtl. L. J. 227 (2018).

Ellickson, Robert. Order Without Law: How Neighbors Settle Disputes. (Harvard Univeristy Press, 1991).

General Allotment Act, 25 U.S.C Ch. 9 \$331 (1887).

Groan, Maura. Native American Lands and Natural Resource Development. Revenue Watch Institute: 6 (2011).

Johnson, Simon, John McMillan, and Christopher Woodruff, "Property Rights and Finance." American Economic Review 95 (2002): 1335-1356.

Hearing on 2019 Bill Text CO S.B. 181 in the Senate Committee on Transportation and Energy (2019) (Statement of Senator Stephen Fenberg, Majority Leader).

Heusner, Grace, Allison Sloto and Joshua Ulan Galperin, "Defining and Closing the Hydraulic Fracturing Governance Gap.” Denver Law Review 95 (2017): 191-260. 
Kovaleski, Jennifer and Nicole Brady, "Bill Overhauling Oil and Gas Regulation gets First Hearing Tuesday After Competing Rallies," The Denver Channel, March 5, 2019, https://www.thedenverchannel.com/news/local-news/bill-overhauling-oil-and-gasregulation-gets-first-hearing-tuesday (accessed March 7, 2019).

Knight, Jamal and Bethany Gullman, "The Power of State Interest: Preemption of Local Fracking Ordinances in Home-Rule Cities.” Tulane Environmental Law Journal 28 (2015): 297-314.

Lee, David and Thomas Lemieux. "Regression Discontinuity Designs in Economics." Journal of Economic Literature 48 (2010): 281- 355.

Lewis, Eric. "Patchwork Policies, Spillovers, and The Search for Oil and Gas." American Economic Journal: Economic Policy 11 no.1 (2019): 380-405.

Leonard, Bryan and Gary D. Libecap. "Economic Analysis of Property Rights: First Possession of Water in the American West." Nat'l Bureau of Econ. Research, Working Paper No. 22185, (2016).

Libecap, Gary. "Federal Lands, Opportunity Costs, And Bureaucratic Management." NBER Working Paper 24705 (2018).

Libecap, Gary and Dean Lueck. "The Demarcation of Land and the Role of Coordinating Property Institutions." Journal of Political Economy 119 (2011): 426-467.

Limerick, Patricia. The Legacy of Conquest: The Unbroken Past of the American West, (Norton \& company, 2006).

Natural Gas Intelligence, "Information on the San Juan Basin,” March 2019, https://www.naturalgasintel.com/sanjuaninfo (accessed March 18, 2019).

North, Douglas, Institutions, Institutional Change, and Economic Performance. (Cambridge Univeristy Press, 1990).

Pisani, Donald. "Enterprise and Equity: A Critique of Western Water Law in the Nineteenth Century." Western Historical Quarterly 18 (1987): 15-37.

Pugliese, Rose. "Demand State Lawmakers to Reject Senate Bill 181," The Daily Sentinel, Mar. 14, 2019, https://www.gjsentinel.com/opinion/columns/demand-state-lawmakers-toreject-senate-bill/article 53a80696-45f0-11e9-8e3d-20677ce85d90.html (accessed March 18, 2019). 
Regan, Shawn. "Tribal Energy Resources: Reducing Barriers to Opportunity.” PERC report (2018).

Robertson, Heidi Gorovitz, “When States' Legislation and Constitutions Collide with Angry Locals: Shale Oil and Gas Development and Its Many Masters." William and Mary Environmental Policy Review 41 (2016): 58-149.

Rosalie D. Morgan, "What The Frack?: An Empirical Analysis of the Effect of Regulation on Hydraulic Fracturing." 16 Quinnipiac Health L. J. 77, 108 (2013).

Royster, Judith. "Mineral Development in Indian Country: The Evolution of Tribal Control Over Mineral Resources." Tulsa Law Journal 29 (1994).

Ryals v. City of Englewood, 2016 CO 7, P.3d 900.

Smith, James. "World Oil: Market or Mayhem?.” Journal of Economic Perspectives 23 no.3 (2009): 145-164.

Southern Ute Indian Tribe Department of Energy, Exploration \& Production Operator's Manual for Energy Development Projects on the Southern Ute Indian Reservation (2018), https://www.suitdoe.com/wp-content/uploads/sites/9/2018/07/SUIR-Operators-ManualJune-2018-Update.pdf (accessed October 3, 2019).

Thistlethwaite, Donald and Donald Campbell. "Regression-Discontinuity Analysis: An Alternative to The Ex Post Facto Experiment." 51 no.6 Journal of Educational Psychology 51(6) (1960): 309-317.

Tribal Energy Resources: Reducing Barriers to Opportunity: Before The Committee on Oversight and Government Reform Subcommittee on the Interior, Energy, and Environment (2018) (Statement of Honorable Adam Red Councilman, Southern Ute Indian Tribal Council).

United States v. Cook, 86 U.S. 591 (1873).

United States v. Shoshone Tribe of Indians, 304 U.S. 111 (1938).

Winslow Constro. Co. v. City \& Cty. Of Denver, 960 P.2d 685,693-95 (Colo. 1998)

Wyoming v. Zinke, No. 16-8068 (10 ${ }^{\text {th }}$ Cir. 2017).

2019 Bill Text CO S.B. 181: Protect Public Welfare Oil and Gas Operations: Concerning additional public welfare protections regarding the conduct of oil and gas operations. Doi: https://leg.colorado.gov/bills/sb19-181.

96 STAT. 1938. 